\title{
Genetic diversity and productivity of Gracilaria coronopifolia as alternative for food resource based on RAPD marker
}

\author{
GUT WINDARSIH $^{1, \bullet}$, DWINITA WIKAN UTAMI ${ }^{2}$, SITI YURIYAH ${ }^{2}$ \\ ${ }^{1}$ Program of Biology, Faculty of Education and Teachers Training, Universitas Islam Negeri Sultan Maulana Hasanuddin Banten. Jl. Syech Nawawi Al \\ Bantani, Serang City 42171, Banten, Indonesia. Tel.+62-254-200-323, `email: gut.windarsih@uinbanten.ac.id, gutwindarsihck@gmail.com \\ ${ }^{2}$ Indonesian Center for Agricultural Biotechnology and Genetic Resource Research and Development. J1. Tentara Pelajar No. 3A, Bogor 16111, West \\ Java, Indonesia
}

Manuscript received: 26 October 2019. Revision accepted: 26 November 2019.

\begin{abstract}
Windarsih G, Utami DW, Yuriyah S. 2019. Genetic diversity and productivity of Gracilaria coronopifolia as alternative for food resource based on RAPD marker. Biodiversitas 20: 3758-3765. Gracilaria coronopifolia is one of potential seaweed as an alternative for food resources, especially for agar source. The information about the genetic profile of G. coronopifolia will be useful for assisting in conservation and breeding efforts. RAPD marker is expected to be utilized for characterization of the species with high productivity based on genetic profile. This research aims to determine the genetic diversity and productivity of G. coronopifolia based on RAPD marker. The samples were collected from Anyer Beach, Banten, Indonesia i.e. Tanjung Tum Beach, Mambruk Hotel Beach, and Patra Comfort Anyer Beach, as well as the cultivation ponds of seaweed in Lontar Village, Banten, Indonesia. Five RAPD primers (OPA-01, OPA-16, OPT-05, OPR-02, and UBC-594) were screened to characterize the genetic profile of samples. The results showed that all primers produced polymorphic bands. Based on the genetic profile, the samples of G. coronopifolia were separated into two main clusters, consisted of group A (Tanjung Tum Beach, Patra Beach, and Mambruk Beach) with a coefficient of similarity of 0.44 and group B (Lontar Village) with a similarity coefficient of 0.43 . The sample from Lontar Village was separated outside from the other three samples at the waters of Anyer Beach. The sample from Lontar Village had the highest talus height $(18.0 \mathrm{~cm})$ and dry weight ( $1.250 \mathrm{~g} /$ clump). The UBC-594 primer was the most associated with the talus height and dry weight on the band size of $50 \mathrm{bp}$, thus this primer was assumed can be used as a selection marker for the talus height and dry weight of G. coronopifolia.
\end{abstract}

Keywords: Alternative food resource, genetic diversity, Gracilaria coronopifolia, productivity, RAPD marker

\section{INTRODUCTION}

Seaweed has been utilized for different purposes (Nazni and Deepa 2015). Seaweed can be utilized for food source, culture medium for research purpose, fertilizers (Delaney et al. 2016), and binding material in lime for painting wall (Smith et al. 2010). Seaweed is valuable source of nutrients, such as vitamins, minerals, proteins, polysaccharides, and dietary fibers (Almeida et al. 2011). Seaweed also contains bioactive primary and secondary metabolites, such as carotenoids, terpenoids, vitamins, fatty acids, amino acids, acetogenins, polyphenols, alkaloids, agar, carrageenan, proteoglycans, alginate, laminarin, rhamnan sulfate, galactosyl glycerol and fucoidan (CenPacheco et al. 2010; Klisch and Hader 2008; Pallela et al. 2010; D'Ayala et al. 2008; Guven et al. 2010; Cabrita et al. 2010), so it is potential for medicinal purposes, such as allelopathic, antimicrobial, antifouling, herbivore deterrent, ultraviolet-screening agents, or as material for pharmaceutical industry to treat diseases like cancer, inflammation, arthritis, and infection for bacteria and fungus (Almeida et al. 2011).

Genus Gracilaria consists of more than 170 species worldwide, distributed from tropical to temperate waters, from intertidal to subtidal zones (Ganesan et al. 2011; Gulbranses et al. 2012). Gracilaria coronopifolia J. Agardh (family Gracilariaceae, Rhodophyta) is one of potential seaweed with the economic value that can be found in the waters of Anyer Beach, Banten (Batu 2012). G. coronopifolia contains water, protein, lipid, carbohydrate, fiber, and ash. The low fat and high fiber contents cause $G$. coronopifolia can be consumed and developed as functional food source (Ate et al. 2017).

The utilization of $G$. coronopifolia in various industrial fields causes the exploitation of seaweed to meet industry needs. The exploitation of $G$. coronopifolia causes a decrease in population and reduces the genetic germplasm in nature. The maintenance of genetic diversity is considered necessary for the existence of species in long time. The decreasing genetic diversity with a loss of certain alleles can decrease the ability of species to respond to the changes of biotic and abiotic environment (Pither et al. 2003).

The molecular markers have been used to analyze the polymorphism of organisms at the molecular level. The advantages of using molecular markers are not influenced by the environment and not destroy the plant (Anggraeni et al. 2008). Random Amplified Polymorphic DNA (RAPD) is one of molecular markers used to identify the genotype of organisms. The polymorphism patterns resulted from RAPD are appropriate for the study of genetic diversity, genetic relationships, and maps (Ayuningrum et al. 2012). Compared to other molecular markers, such as Restriction Fragment Length Polymorphisms (RFLP) and Simple 
Sequence Repeats (SSR), RAPD has the advantages, such as less labour-intensive than other molecular markers (Negi and Joshi 2015), cheaper, easier in utilization, quickly to give the products, produce DNA bands in a large number, no need the information about the background of genome, and easy to get the random primers to analyze the genome of all organisms (Poerba and Martanti 2008). But, the use of RAPD has also the weakness, such as not reliable, because it gives the different product when repeated. This weakness can be overcome by optimizing the extraction, PCR condition, and the appropriate primary selection. RAPD has been applied to study the genetic diversity in some types of seaweeds, i.e. Eucheuma spp. (Ayuningrum et al. 2012; Anggraeni et al. 2008).

The information about the genetic diversity and productivity of $G$. coronopifolia from the coastal waters in Banten has not been widely reported. The RAPD primer can be used to characterize the genetic profile of any species with the targeted traits. The genetic profile of $G$. coronopifolia with high productivity was expected to be characterized for assisting in conservation and breeding efforts. The research aims to determine the genetic diversity and productivity of $G$. coronopifolia from Anyer Beach and the cultivation ponds in Lontar Village, Banten based on RAPD marker.

\section{MATERIALS AND METHODS}

\section{Plant Materials}

The materials used in this research were Gracilaria coronopifolia taken from the waters Anyer Beaches of Anyar (or Anyer) Subdistrict which includes Tanjung Tum Beach, Mambruk Hotel Beach, Patra Comfort Anyer Beach; and Lontar Ponds of Tirtayasa Subdistrict, Serang
District, Banten Province, Indonesia. The locations of sampling were presented in Figure 1 and Table 1.

\section{Procedures}

Sample collection (sampling)

The sampling was conducted at three sampling points in Anyer Beach waters and in the cultivation ponds of Lontar Village, Banten. The sampling locations were determined by a survey method. The sampling was conducted by exploration and collection. The sampling of $G$. coronopifolia was carried out in various types of habitats along the coastal waters, including reef flats, coral basin, sandy area, and around the subtidal zones. The samples were collected mainly at low tide (Trono and GanzonFortes 1988; Sukiman 2011) by taking all parts of talus, then washed and put into plastic bag and labeled (Sukiman 2011). The samples used for identification purpose were stored in a jar containing the preservation solution (70\% ethanol) and labeled. Meanwhile, the fresh samples used for molecular analysis were the tips of branches of $G$. coronopifolia talus about $8 \mathrm{~cm}$ from the end of the branch for the DNA extraction (Ayuningrum et al. 2012). Furthermore, the fresh samples used for molecular analysis were put into plastic bags and stored in freezer at the temperature of $-40^{\circ} \mathrm{C}$.

\section{Observation of morphological characteristics}

The morphological characteristics observed for the identification purpose were talus type, shape, length, texture, color, and branching pattern. The observed characters were recorded and taken for pictures by using a digital camera. The identification of specimens was performed according to Trono and Ganzon-Fortes (1988), and Sukiman (2011). Meanwhile, the morphological characteristics observed for productivity analysis were talus length (height) and dry weight.

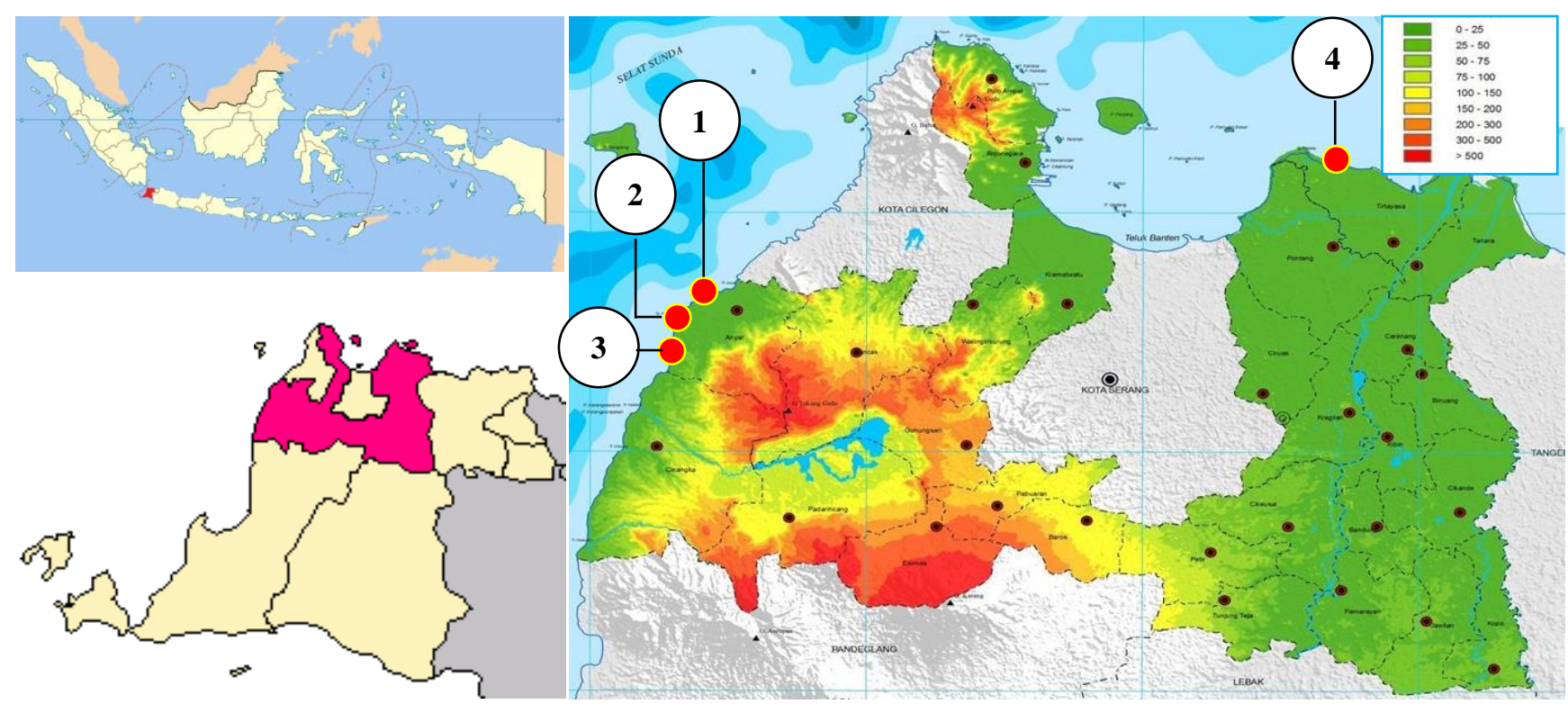

Figure 1. Sampling location in Anyer Beaches (includes: 1. Tanjung Tum Beach, 2. Mambruk Hotel Beach, 3. Patra Comfort Anyer Beach) and Lontar Ponds (4) of Serang District, Banten Province, Indonesia. 
Table 1. The sampling locations of Gracilaria coronopifolia in Anyer Beach and the cultivation pond in Lontar Village, Serang District, Banten, Indonesia

\begin{tabular}{|c|c|c|c|c|c|}
\hline No. & Subdistrict & Village & Area & Location & Position \\
\hline 1 & Anyar & Cikoneng & Anyer Beach & Tanjung Tum Beach & S 603’46.25”; E 10553’43.63” \\
\hline 2 & Anyar & Cikoneng & Anyer Beach & Mambruk Hotel Beach & S 604'19.88”; E 105'52'58.68" \\
\hline 3 & Anyar & Bandulu & Anyer Beach & Patra Comfort Anyer Beach & S 605'27.26”; E 105'52'57.06” \\
\hline 4 & Tirtayasa & Lontar & Lontar ponds & The cultivation pond of G. coronopifolia & S 558'6.74"; E 106¹7'51.02” \\
\hline
\end{tabular}

\section{DNA extraction}

DNA extraction was performed based on the CTAB method according to Delaporta et al. (1983) with modification. The samples were ground in liquid nitrogen and put into 2 $\mathrm{mL}$ microtube and added with $700 \mu \mathrm{L}$ of buffer solution (0.1 M Tris HCl, $0.04 \mathrm{M}$ EDTA, $1.4 \mathrm{NaCl}, 2 \%$ CTAB) then incubated in $65^{\circ} \mathrm{C}$ for $20 \mathrm{~min}$. The samples were added with CI (chloroform: isoamyl-alcohol $=24: 1$ ) at same volume, then shaken and centrifuged at $14000 \mathrm{rpm}$ for $10 \mathrm{~min}$. The supernatant about $500 \mu \mathrm{L}$ was poured into a new microtube $1.5 \mathrm{~mL}$, added with $2 \mathrm{x}$ absolute ethanol, and shaken until the DNA threads have appeared. After precipitation, the samples were centrifuged at $14000 \mathrm{rpm}$ and $4{ }^{\circ} \mathrm{C}$ for $15 \mathrm{~min}$. A pellet was added with $300 \mu \mathrm{L}$ of $70 \%$ alcohol and centrifuged at $14000 \mathrm{rpm}$ for $5 \mathrm{~min}$. After dried, the pellet was added with $50 \mu \mathrm{L}$ TE $1 \mathrm{x}$ and $10 \mu \mathrm{L}$ RNase $10 \mathrm{ng} / \mu \mathrm{L}$, then incubated at $37^{\circ} \mathrm{C}$ for an hour. The inactivation of RNase was performed by incubation at $70^{\circ} \mathrm{C}$ for $10 \mathrm{~min}$. The DNA was checked on $1.5 \%$ agarose gel electrophoresis in TAE $1 \mathrm{x}$ at 100 volts for $30 \mathrm{~min}$.

\section{PCR amplification}

The PCR reaction was performed with the PCR reagent composition consisted of 1x PCR buffer, $0.4 \mathrm{mM}$ dNTPs, $0.6 \mathrm{uM}$ primer, $0.1 \mathrm{U}$ Taq polymerase enzyme, and 10-20 $\mathrm{ng} / \mu \mathrm{L}$ DNA. Five primers were used to amplify DNA of $G$. coronopifolia (Table 2).

The PCR process for RAPD primers consisted of early denaturation at $95^{\circ} \mathrm{C}$ for 1 minute, followed by 40 cycles. Each cycle consisted of denaturation at $95^{\circ} \mathrm{C}$ for 30 seconds, annealing at $36^{\circ} \mathrm{C}$ for 30 seconds, and primer extension at $72^{\circ} \mathrm{C}$ for 30 seconds. The post extension was carried out at $72^{\circ} \mathrm{C}$ for $5 \mathrm{~min}$ and then the reaction was terminated at $12^{\circ} \mathrm{C}$ for $20 \mathrm{~min}$. The PCR product was separated in $1.5 \%$ agarose gel electrophoresis in TAE $1 \mathrm{x}$ with 100 volts and $200 \mathrm{~mA}$ for two hours to determine the DNA band patterns. The DNA bands were then visualized in UV light after soaking in ethidium bromide.

Table 2. Five RAPD primers used for the amplification of DNA fragments

\begin{tabular}{ll}
\hline Primer & Primer Sequence $\left(\mathbf{5}^{\prime} \rightarrow \mathbf{3}\right.$ ') \\
\hline OPA-01 & CAGGCCCTTC \\
OPA-16 & AGCCAGCGAA \\
OPT-05 & GGGTTTGGCA \\
OPR-02 & CACAGCTGCC \\
UBC-594 & AGGAGCTGGC \\
\hline
\end{tabular}

\section{Data analysis}

The analysis of genetic similarity of G. coronopifolia was conducted based on the DNA band pattern of the PCR products based on the RAPD primers. Each DNA band resulted in an electrophoresis rate with the same size as a primer was considered as a single locus. Thus, the same DNA bands from some samples were interpreted as one homologous locus. The DNA band pattern was then converted into the binary data by given a score of one (1) if there was a band and zero (0) if there was no band in the same locus. The binary data of the five RAPD primers resulted were used for genetic similarity analysis. A cluster analysis was conducted by using UPGMA (Unweighted Pair Group Method with Arithmetic Means) through NTSYS (Numerical Taxonomy and Multivariate Analysis System) Program version 2.02 (Rohlf 1997) resulting in the grouping dendrogram of $G$. coronopifolia from various location points of sampling. The value of genetic similarity was obtained based on Simple Matching Coefficient, while the value of genetic dissimilarity was a reduction in the value of similarity matrix by value 1 (Dunn and Everitt 1982).

The association between the genotype characteristic based on the RAPD marker with the productivity characteristics (talus height and dry weight of talus) was analyzed by using Tassel Program version 2.0. The marker (s) associated with the productivity characters (p_value $<0.5$ ) indicate that it can be used as the selection marker (s) for talus height and dry weight of talus characters. From this analysis, the genetic distance matrix of samples inter-location was also obtained.

\section{RESULTS AND DISCUSSION}

\section{Morphology characteristic}

Gracilaria coronopifolia showed an erect or falling talus with height about $4.5-15 \mathrm{~cm}$, laevis surface, purple, red, blackish, or greenish-yellow color, had cylindrical talus on the axis with diameter about 1.2-2.0 mm. The holdfast was like a disk attached to substrates. The branches of talus were irregular, alternate, and dichotomy with the base of branches was slightly narrow, short and growing irregularly on talus axis, the branches tapered to the tip and short (1.0-2.5 mm), dichotomy with unequal size and pointed tip of branches. Gracilaria coronopifolia can be found attached to coral reef, sand, sponges, or epiphytes in seagrass, cosmopolitan or spread. Gracilaria coronopifolia had also widely been cultivated in ponds. 


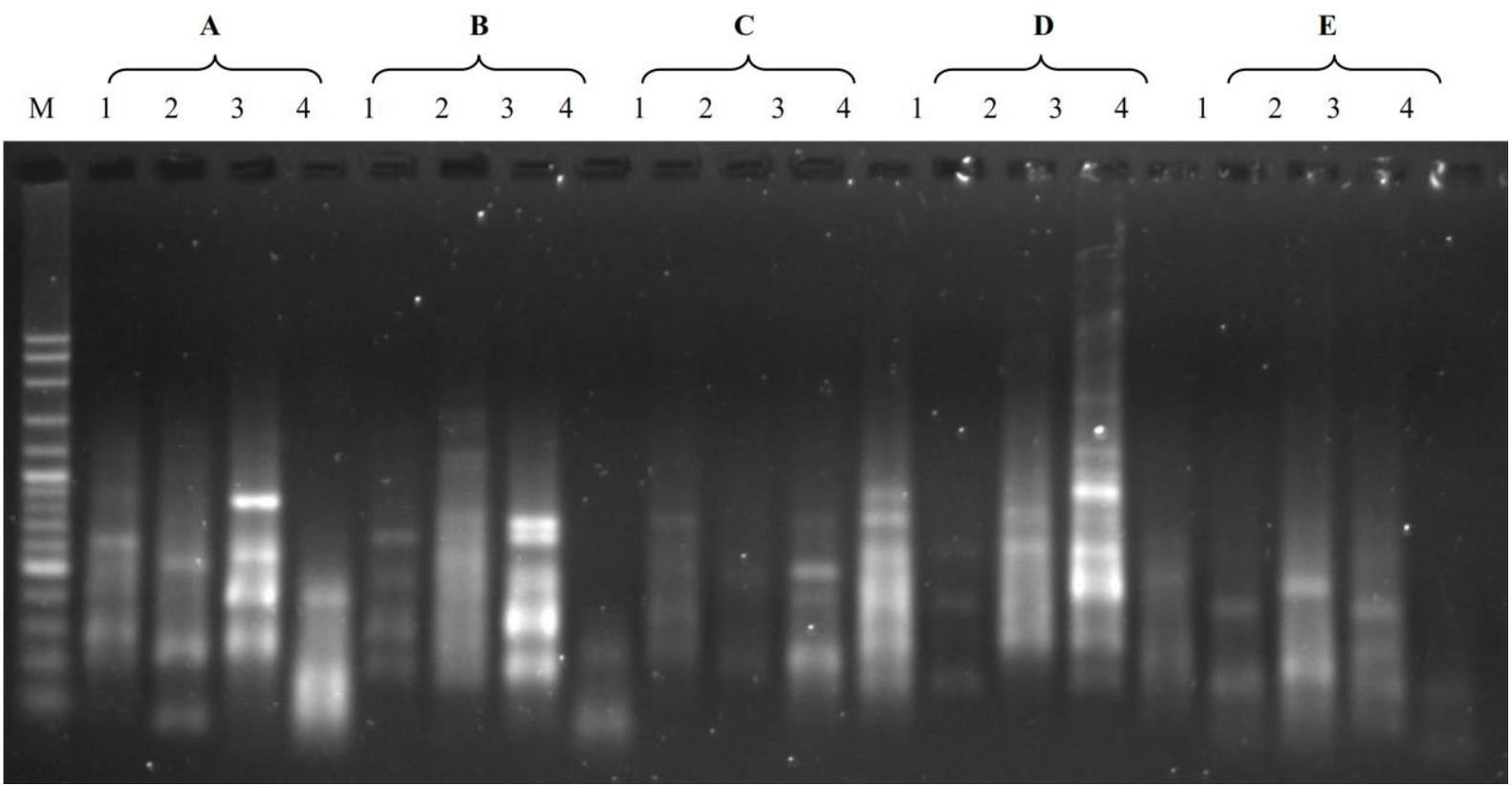

Figure 2. The result of DNA amplification based on RAPD markers on Gracilaria coronopifolia collected from the Anyer Beach area and the cultivation ponds of seaweed in Lontar Village. A. Primer OPA-01, B. primer OPA-16, C. primer OPT-05, D. primer OPR-02, E. primer UBC-594, 1. Tanjung Tum Beach, 2. Mambruk Hotel Beach, 3. Patra Comfort Anyer Beach, 4. The cultivation ponds of seaweed in Lontar Village, Banten, $\mathrm{M}=$ DNA ladder $100 \mathrm{bp}$

Table 3. Polymorphism of DNA scored from five RAPD primers on Gracilaria coronopifolia collected from the Anyer Beach waters and the cultivation ponds in Lontar Village, Banten, Indonesia

\begin{tabular}{lccc}
\hline Primer & $\begin{array}{c}\text { Total of } \\
\text { DNA } \\
\text { band }\end{array}$ & $\begin{array}{c}\text { The number of } \\
\text { polymorphism } \\
\text { band }\end{array}$ & $\begin{array}{c}\text { Polymorphism } \\
\text { level (\%) }\end{array}$ \\
\hline OPA-01 & 9 & 9 & 100 \\
OPA-16 & 12 & 12 & 100 \\
OPT-05 & 11 & 11 & 100 \\
OPR-02 & 10 & 10 & 100 \\
UBC-594 & 9 & 9 & 100 \\
Total & 51 & 51 & 100 \\
\hline
\end{tabular}

\section{DNA profile}

A total of five RAPD primers were screened to produce the polymorphic bands on $G$. coronopifolia, consisted of OPA-01, OPA-16, OPT-05, OPR-02, and UBC-594 primers. The result of DNA amplification with five primers showed the different intensity of DNA bands (Figure 2).

The results showed that the appearance of DNA bands generated by OPA-02 and OPA-16 primers was more clearly than OPT-05, OPR-02, and UBC-594 primers. The DNA amplification on Amorphophallus muelleri Blume based on RAPD marker was also not always obtained the same intensity bands (Poerba and Martanti 2008). The intensity differences of amplified DNA bands from each primer are influenced by several factors, i.e. the level of purity and the concentration of DNA template. The DNA template containing the natural compounds, such as polysaccharides and phenolic compounds, and the low concentration of DNA template often produces unclear DNA bands. The distribution of primer annealing site and the annealing competition on the DNA template cause a fragment to be amplified in large quantities and other fragments in small amount. Meanwhile, the amplification process can be initiated in several sites, but only a few sites can be detected as DNA bands resulted from amplification. Each primer has specific attachment site, so the polymorphic DNA bands generated by each primer are different (Weeden et al. 1992; Poerba and Martanti 2008). $G$. coronopifolia has a large polysaccharide content. The compound could be a source of contaminants in DNA amplification, so it causes some primers to produce unclear amplified DNA.

The amplification of four samples of G. coronopifolia taken from the Anyer Beach area (Tanjung Tum Beach, Patra Comfort Anyer Beach, Mambruk Beach) and the cultivation ponds in Lontar Village showed that the all primers produced polymorphic bands with 100\% polymorphism. These values indicate that the primers can be used to detect the genetic variation in all samples of $G$. coronopifolia analyzed. From the five primers, it was obtained 51 DNA fragments with sizes between $50 \mathrm{bp}$ to $1700 \mathrm{bp}$. The five primers produced between 9-13 DNA bands that could be detected and scored, with an average of each primer produced 10.4 fragments and the maximum number of polymorphic bands were produced by OPA-16 primer (Table 3).

\section{Cluster analysis}

The cluster analysis of genetic similarity based on the RAPD marker showed that the four samples of $G$. 
coronopifolia analyzed had a low similarity coefficient ranged between $0.43-0.55$. Overall, the five primers were able to separate the samples into two main clusters, consisted of group A (Tanjung Tum Beach, Patra Beach, and Mambruk Beach) with a coefficient of similarity by 0.44 and group B (the pond of seaweed in Lontar Village) with a similarity coefficient of 0.43 (Figure 3). Cluster A consisted of two sub-clusters, namely sub-cluster 1 that consisted of the samples from Tanjung Tum Beach and Patra Beach, and another one sub-cluster by the sample from Mambruk Beach. From the four samples of $G$. coronopifolia analyzed, the samples from Tanjung Tum Beach and Patra Beach had the highest similarity coefficient of 0.55 (Figure 4). Meanwhile, the value of genetic dissimilarity for four samples of $G$. coronopifolia ranged between $0.45-0.57$, with the highest value $(0.57)$ was obtained between Lontar Village and Mambruk Hotel Beach, and the lowest value (0.45) was obtained between the samples from Tanjung Tum Beach and Patra Beach.

The genetic distance values of samples inter-locations ranged between 0.4444-0.5926 (Table 4). The highest genetic distance was obtained between the samples from Mambruk Hotel Beach with Patra Beach (0.5926) and between the samples from Patra Beach with Lontar Village (0.5926). Meanwhile, the lowest genetic distance was obtained between the samples from Patra Beach with Tanjung Tum Beach (0.4444).

The cluster analysis showed that the adjacent sample locations (Tanjung Tum Beach, Patra Beach, Mambruk Beach) tend to form one group. Meanwhile, the $G$. coronopifolia sample in Lontar Village was separated from the three samples in the waters of Anyer Beach with the lowest genetic similarity of 0.43 . The four samples of $G$. coronopifolia analyzed had a low similarity coefficient. This showed that the samples were not identical. From the four samples of $G$. coronopifolia analyzed, the samples from Tanjung Tum Beach and Patra Beach had the highest similarity coefficient. The vegetative development of $G$. coronopifolia is through the formation of spores. This allows the occurrence of spores attachment on the talus of seaweed located at the adjacent location. Therefore, it produces a close genetic similarity among the adjacent samples.

The genetic diversity of $G$. coronopifolia could be influenced by several factors. A high genetic diversity on G. coronopifolia cultivated in Lontar was assumed to be caused by an asexual reproduction through the vegetative fragmentation. The pattern of cultivation applied by people in Lontar Village was generally conducted by using the talus harvested from previous cultivation as new seedlings. Therefore, it might minimize a gene flow, causes a low opportunity of recombination at meiosis and produces a new progeny/filial through fertilization (Zuccarello et al. 2006; Hayward et al. 1993). Meanwhile, low genetic diversity of $G$. coronopifolia between the samples from Tanjung Tum Beach and Patra Beach might be caused by the higher probability of sexual reproduction across the waters causing a gene flow inter-locations.

The seaweed seedling of $G$. coronopifolia cultivated in Lontar Village was obtained from the Indonesian Institute of Sciences (LIPI) (www.kompasiana.com). The seedling is the superior variety obtained through the breeding technique, so it was assumed to cause G. coronopifolia from Lontar Village was genetically different from the wild varieties taken from the waters of Anyer Beach. Thus, the sample G. coronopifolia cultivated in Lontar Village had a high genetic variation (43\%) compared with wild samples from the waters of Anyer Beach. Meanwhile, the genetic distance between samples from Patra Beach and Tanjung Tum Beach was low. This result showed a probability that both samples (Patra Beach and Tanjung Tum Beach) derived from the same parents/clones.

\section{Productivity of Gracilaria coronopifolia}

The productivity observation of $G$. coronopifolia was conducted for talus height and dry weight. The sample of $G$. coronopifolia from the cultivation ponds in Lontar Village had higher talus height $(18.0 \mathrm{~cm})$ and dry weight ( $1.250 \mathrm{~g} / \mathrm{clump})$ compared to the three samples from Anyer Beach waters (Table 5, Figure 4).

\section{Association between DNA profile and productivity}

The association between the DNA profile and the phenotype characteristics, including talus height and dry weight, were analyzed using Tassel 2.2 Program. The results showed that from five primers, primer UBC-594 associated with the talus height of $G$. coronopifolia (p_value $=0.000$ ) on the band size of $50 \mathrm{bp}$. Meanwhile, all primers (OPA-01, OPA-16, OPT-05, OPR-02, UBC-594) associated with the dry weight of $G$. coronopifolia with p_value $<0.05$ (Table 6, Figure 3 ).

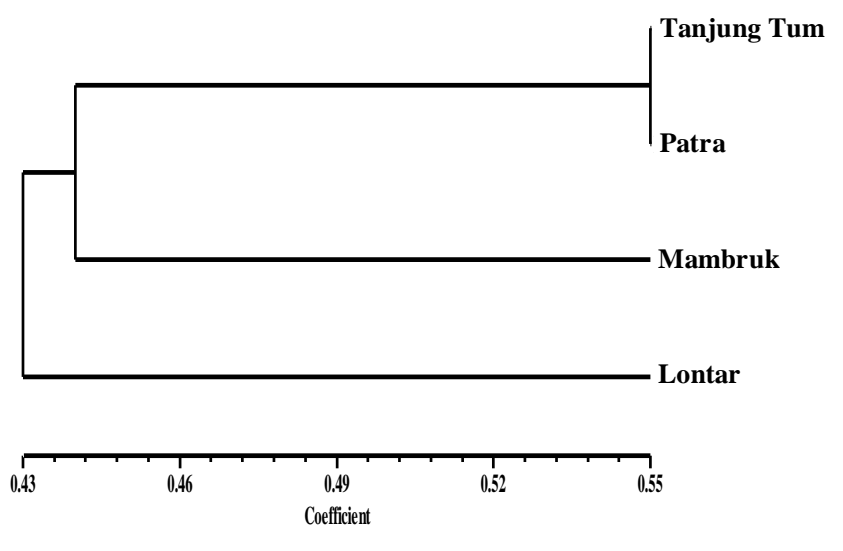

Figure 3. The dendrogram of the genetic similarity based on the UPGMA analysis using five RAPD markers on Gracilaria coronopifolia

Table 4. The genetic distance matrix of Gracilaria coronopifolia samples from four locations

\begin{tabular}{lcccc}
\hline \multicolumn{1}{c}{ Location } & $\begin{array}{c}\text { Tanjung } \\
\text { Tum }\end{array}$ & Mambruk & Patra & Lontar \\
\hline Tanjung Tum & 0.0000 & & & \\
Mambruk & 0.4815 & 0.0000 & & \\
Patra & 0.4444 & 0.5926 & 0.0000 & \\
Lontar & 0.4815 & 0.5556 & 0.5926 & 0.0000 \\
\hline
\end{tabular}




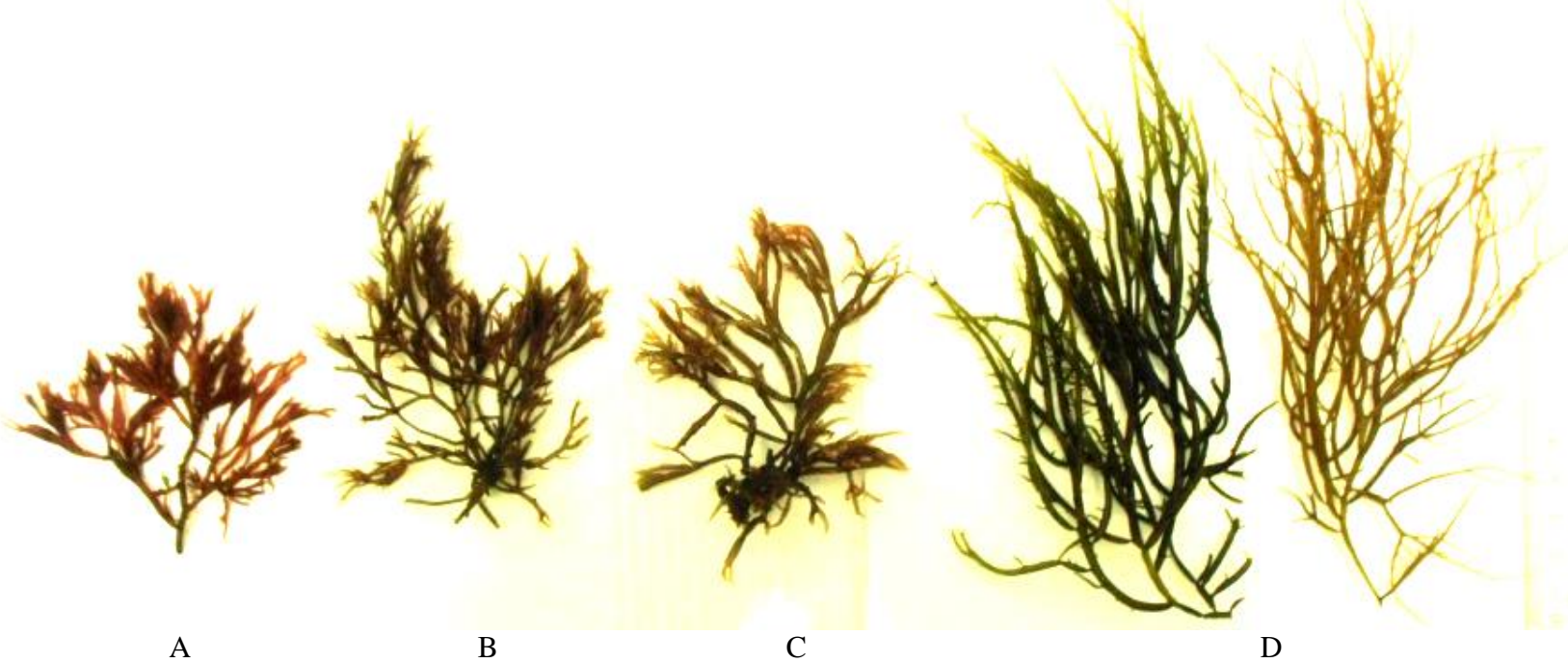

Figure 4. The sample of Gracilaria coronopifolia collected from: (A) Tanjung Tum Beach, (B) Mambruk Hotel Beach, (C) Patra Comfort Anyer Beach, and (D) The cultivation ponds in Lontar Village, Banten

Table 5. Talus height and dry weight of Gracilaria coronopifolia

\begin{tabular}{lcc}
\hline Location of sample & $\begin{array}{c}\text { Average of } \\
\text { talus height }(\mathbf{c m})\end{array}$ & $\begin{array}{c}\text { Average of } \\
\text { dry weight (g/clump) }\end{array}$ \\
\hline Tanjung Tum Beach & 7.5 & 0.137 \\
Mambruk Hotel Beach & 11.1 & 0.158 \\
Patra Beach & 8.4 & 0.343 \\
Lontar Village & 18.0 & 1.250 \\
\hline
\end{tabular}

Table 6. The association between DNA profile and productivity of Gracilaria coronopifolia

\begin{tabular}{lllc}
\hline Primer & \multicolumn{1}{c}{ Band size (bp) } & $\begin{array}{c}\text { Primer } \\
\text { associated with }\end{array}$ & p_marker \\
\hline OPA-01 & $75,400,890$ & Talus dry weight & 0.015 \\
OPA-16 & 175 & Talus dry weight & 0.015 \\
OPT-05 & $200,400,500,710$ & Talus dry weight & 0.015 \\
OPR-02 & $125,420,1800$ & Talus dry weight & 0.015 \\
UBC-594 & 75 & Talus dry weight & 0.015 \\
UBC-594 & 50 & Talus dry weight & 0.000 \\
UBC-594 & 50 & Talus height & 0.000 \\
\hline
\end{tabular}

The higher talus height and dry weight, the higher productivity of $G$. coronopifolia. The data obtained from this study suggested that $G$. coronopifolia cultivated in Lontar Village tend to have higher productivity than the samples from the waters of Anyer Beach. The association between the genetic profile and the productivity character showed that the primer UBC-594 was the most precision to the dry weight of talus with p_value $=0.000$ on the band size of $50 \mathrm{bp}$ (Table 6, Figure 3 ). This result showed that primer UBC-594 could be used as the selection marker for the talus height and dry weight of $G$. coronopifolia on the band size of $50 \mathrm{bp}$. The sequencing of the DNA band precisely associated with the productivity of talus can be conducted to design a new selection marker for detecting G. coronopifolia with high quality in nature.

The RAPD marker of primer UBC-594 can be used to characterize genetically the productivity of $G$. coronopifolia as alternative food resource. The future research can be focused especially on characterization of agar production with high quality based on RAPD marker and to design a new specific primer for genotype selection. The efforts of conservation, cultivation, and breeding on $G$. coronopifolia were recommended to be conducted based on the genetic diversity and productivity of wild germplasms, so it can protect the sustainability of species and improve the productivity.

\section{ACKNOWLEDGEMENTS}

We thank Dadang and Edi from the Indonesian Center for Agricultural Biotechnology and Genetic Resource Research and Development (ICABIOGRAD), Bogor, Indonesia for helping the DNA extraction and the PCR process. This research was funded by the State Islamic University of Sultan Maulana Hasanuddin Banten through the Individual Research Funding No. 281 the Year 2017.

\section{REFERENCES}

Almeida CLF, Falcão HS, Lima GRM, Montenegro CA, Lira NS, Athayde-Filho PF, Rodrigues LC, Souza MFV, Barbosa-Filho JM, Batista LM. 2011. Review: Bioactivities from marine algae of the Genus Gracilaria. Intl J Mol Sci 12: 4550-4573. DOI: 10.3390/ijms12074550. 
Anggraeni SR, Sudarsono, Soedharma D. 2008. Karakterisasi genetika rumput laut Eucheuma spp. dari tiga daerah di Indonesia (Kepulauan Seribu, Keruak, dan Sumenep). Jurnal Bionatura 10: 196-208. [Indonesian]

Ayuningrum PI, Afrianto E, Mulyani Y. 2012. Keragaman genetik rumput laut Eucheuma spp. dari Sukabumi, Jawa Barat berdasarkan metode RAPD PCR. Jurnal Perikanan dan Kelautan 3: 337-345. [Indonesian]

Batu RBP. 2012. Keragaman Fenotipe Rumput Laut Gracilaria spp. yang Dibudidayakan di Tambak Desa Langensari, Subang. [Essay]. Institut Pertanian Bogor, Bogor. [Indonesian]

Cabrita MT, Vale C, Rauter AP. 2010. Halogenated compounds from marine algae. Mar Drugs 8: 2301-2317.

Cen-Pacheco F, Nordstrom L, Souto ML, Martin MN, Fernandez JJ, Daranas AH. 2010. Studies on polyethers produced by red algae. Mar Drugs 8: 1178-1188.

D’Ayala GG, Malinconico M, Laurienzo P. 2008. Marine derived polysaccharides for biomedical applications: Chemical modification approaches. Molecules 13: 2069-2106.

Delaney A, Frangoudes K, Li SA. 2016. Society and seaweed: understanding the past and present. In: Fleurence J, Levine I (eds.) Seaweed in Health and Disease Prevention. Elsevier Academic Press, London.

Ganesan M, Sahu N, Eswaran K. 2011. Raft culture of Gracilaria edulis in open sea along the south-eastern coast in India. Aquaculture 321 (1-2): 141-151.

Gulbranses DJ, McGlathery KJ, Marklund M, Norris JN, Gurgel CFD. 2012. Gracilaria vermiculophylla (Rhodophyta, Gracilariales) in the Virginia coastal Bays, USA: coxl analysis reveals high genetic Richness of an introduced macroalga. J Phycol 48 (5): 1278-1283.

Guven KC. Percot A, Sezik E. 2010. Alkaloids in marine algae. Mar Drugs 8: 269-284.

Klisch M, Hader DP. 2008. Mycosporine-like amino acids and marine toxins-The common and the different. Mar Drugs 6: 147-163.
Pallela R, Na-Young Y, Kim SK. 2010. Anti-photoaging and photoprotective compounds derived from marine organisms. Mar Drugs 8: 1189-1202.

Nazni P, Deepa S. 2015. Evaluation of proximate and pigment composition of red seaweed in South Coastal Regions of Tamilnadu. Int J Res Mar Sci 4 (2): 38-41.

Negi RK, Joshi BD. 2015. Genetic diversity between populations of the genus Schistura McClelland from the Garhwal and Kumaun Region using RAPD marker. Asian J Biotech 7: 71-79.

Poerba YS, Martanti D. 2008. Keragaman genetik berdasarkan marka Random Amplified Polymorphic DNA pada Amorphophallus muelleri Blume di Jawa. Biodiversitas 9: 245-249. [Indonesian]

Pither R, Shore JS, Kellman M. 2003. Genetic diversity of the tropical tree Terminalia amazonia (Combretaceae) in naturally fragmented populations. Heredity 91: 313-317.

Rohlf FJ. 1997. NTSYS-pc: Numerical Taxonomy and Multivariate Analysis Version 2.00. Exeter Software, New York.

Smith JL, Summers G, Wong R. 2010. Nutrient and heavy metal content of edible seaweeds in New Zealand. J Crop Horticult Sci 38 (1): 1928.

Sukiman. 2011. Biodiversitas dan Potensi Ganggang Merah (Rhodophyta) di Perairan Pantai Jawa Barat. [Thesis]. Institut Pertanian Bogor, Bogor. [Indonesian]

Trono GC, Ganzon-Fortes ET. 1988. Philippine Seaweeds. National Book Store Inc., Manila.

Weeden NF, Timmerman GM, Hemmat M, Kneen BE, Lodhi MA. 1992. Inheritance and reliability of RAPD markers. Application of RAPD Technology to Plant Breeding. Joint Plant Breeding Symposia Series, November 1, 1992, Minneapolis, MN, Crop Science Society of America, Madison, WI

Zuccarello GC, Cricthley AT, Smith J, Sieber V, Lhonneur GB, West JA. 2006. Systematic and genetic variation in commercial Kappaphycus and Eucheuma (Solieriaceae, Rhodophyta). J Appl Phycol 18: 643651. DOI: 10.1007/s10811-006-9066-2. 